\title{
THE ROLE OF TECHNOLOGY ACCEPTANCE MODEL ON EMAIL USAGE AMONG ACADEMICIAN IN MALAYSIAN PUBLIC AND PRIVATE UNIVERSITIES
}

\author{
Anuar Shah Bali Mahomed ${ }^{1}$, Michael G. McGrath², Bong Zhi Yuh ${ }^{3}$, Shafie Sidek ${ }^{4}$, \\ Saadiatul Ibrahim ${ }^{5}$, Zulbasri Othman ${ }^{6}$ \\ 1, 4,5 Department of Management and Marketing, Universiti Putra Malaysia,43400, Malaysia \\ ${ }^{2}$ College of Business, Victoria University Melbourne, 8001, Australia \\ ${ }^{3}$ Double B, Department Research and Analytic, 70000, Malaysia \\ ${ }^{6}$ Department of Human Resource and Development, Universiti Pertahanan \\ Nasional Malaysia, 57000 Malaysia \\ E-mails:1'anuar@upm.edu.my (corresponding author); ${ }^{2}$ Michael.McGrath@vu.edu.au; \\ 3bong.analysis@gmail.com; ${ }^{3}$ shafiesidek@upm.edu.my; ${ }^{5}$ saida@upm.edu.my; \\ ${ }^{6}$ zulbasri@upm.edu.my
}

\begin{abstract}
This study examines the levels and factors contributing to email usage among academician in Malaysian universities. The Technology Acceptance Model (TAM) was tested to investigate the relationship of perceived ease of use (PEOU) and perceived usefulness (PU) on email usage (U). By using survey questionnaires, data was collected from 274 academician in Malaysian public and private universities. Path analysis was conducted using SmartPLS 2.0 to examine the research model. This research found that email usage among academician in Malaysian private universities is significantly higher than Malaysian public universities, albeit the usage were high for both types of universities.
\end{abstract}

Keywords: email, academician, Technology Acceptance Model (TAM), Perceived Ease of Use (PEOU) and Perceived Usefulness (PU)

JEL Classification: M10, M14, M15.

\section{Introduction}

The use of electronic mail or email for communication is being heavily promoted by the government of Malaysia, in hopes of improving the performance as well as communication, yet it is plague by multiple problems for its full implementation as suggested by Mahomed (2015). For example, a research conducted by Southeast Asia Consumer Insights covering about as much 3,600 consumers from Southeast Asian to observe their behaviour in Philippines, Singapore and Malaysia online. The research discovered that whether from home or outside, Southeast Asian consumers will use their emails. On top of that they are open when it comes to making a purchase from the email they receive.

The result show that Malaysia has a lower percentage of email users who check on their email at least for a day which is 87 percent compared to that of the Philippines as well as Singapore who both tie at 90 percent of usage (Beechler, 2014).
A newer study conducted by Get Response (2017) on Southeast Asia email marketing benchmarks found that almost half of all emails sent in Southeast Asia come from Get Response customers in Singapore, followed by $17 \%$ in Malaysia, $16 \%$ in Vietnam, and $14 \%$ in Thailand. Although the number of newsletters sent in Singapore is consistent with the other countries, the actual sends to mailboxes is significantly higher. This shows that companies in Singapore on average have more subscribers than other countries in Southeast Asia. Among our Southeast Asian customers, we see a high average open rate of $45.98 \%$ in Vietnam, compared to the rest of the region. At the other end of the spectrum, Malaysia has the lowest average open rate of $16.52 \%$. In clickthrough rates, Thailand has the highest average at $10.41 \%$, with Malaysia and Indonesia being the lowest at $2.39 \%$ and $2.74 \%$ respectively. The details as in the Table 1 below.

Moreover, the study also found that among their customers in Southeast Asia, the industry 
with the highest average open rate is the education industry, with an average open rate of $41.06 \%$. However, open rate for Malaysia in education industry is the lowest which is 24.46 as compared to other Southeast Asia countries (Get Response, 2017). The details as in the Table 2 below.

The study done by Mahomed (2015) in regards to email use between non-academic staffs in universities of Malaysian showed that $21.9 \%$ staffs received more than 20 messages a day and $50 \%$ of the staffs sent out less than 5 messages or equal within a day. The comparison of emails received by non-academic staffs in both universities showed that private universities had higher number of official emails, on which private universities was ranked 234.41 level and public universities was ranked 173.44 level. The comparison of emails received by non-academic staffs in both universities showed that private universities had higher number of official emails, where by private universities were ranked 235.79 level and public universities were ranked 172.26 (Mahomed, 2015).

The above examples all appear to indicate that there are real issues and problems associated with the lower adoption and use of email in Malaysia. Moreover, as is outlined below, the nation's universities do not appear to be immune from this problem. Some of the findings also show that academician in Malaysian private universities show more level of ICT proficiencies when seen side by side with those in public universities (Dawam et al., 2009). In fact, academician in private universities showed higher computer literacy in regards to those from the public universities (Dawam et al., 2009). It must, however, be added that Dawan et al. (2009) study was conducted 9 years ago and the rapid changes of technologies may contributing to a possible different finding.

Table 1. Southeast Asia Email Marketing Benchmarks. Results are from March through May 2017 (source: reproduced from Get Response, 2017)

\begin{tabular}{|l|c|c|c|c|}
\hline Country & $\begin{array}{c}\text { Open } \\
\text { Rate } \\
(\%)\end{array}$ & $\begin{array}{c}\text { Click- } \\
\text { through } \\
\text { Rate (\%) }\end{array}$ & $\begin{array}{c}\text { Unsub- } \\
\text { scribe } \\
\text { Rate (\%) }\end{array}$ & $\begin{array}{c}\text { Spam } \\
\text { Rate } \\
(\%)\end{array}$ \\
\hline Malaysia & 16.52 & 2.39 & 0.10 & 0.01 \\
\hline Singapore & 20.25 & 3.69 & 0.13 & 0.02 \\
\hline Indonesia & 25.72 & 2.74 & 0.10 & 0.01 \\
\hline Thailand & 26.67 & 10.41 & 0.15 & 0.01 \\
\hline Philippines & 22.73 & 3.64 & 0.16 & 0.02 \\
\hline Vietnam & 45.98 & 6.38 & 0.13 & 0.01 \\
\hline
\end{tabular}

Table 2. Southeast Asia Email Marketing Benchmarks (Education Industry). Results are from March through May 2017 (source: reproduced from Get Response, 2017)

\begin{tabular}{|l|c|c|c|c|}
\hline Country & $\begin{array}{c}\text { Open } \\
\text { Rate } \\
(\%)\end{array}$ & $\begin{array}{c}\text { Click- } \\
\text { through } \\
\text { Rate (\%) }\end{array}$ & $\begin{array}{c}\text { Unsub- } \\
\text { scribe } \\
\text { Rate (\%) }\end{array}$ & $\begin{array}{c}\text { Spam } \\
\text { Rate } \\
(\%)\end{array}$ \\
\hline Malaysia & 24.46 & 3.41 & 0.11 & 0.01 \\
\hline Singapore & 31.78 & 3.39 & 0.11 & 0.01 \\
\hline Indonesia & 36.79 & 4.72 & 0.12 & 0.00 \\
\hline Thailand & 73.76 & 12.99 & 0.15 & 0.01 \\
\hline Philippines & 41.04 & 4.42 & 0.07 & 0.01 \\
\hline Vietnam & 41.06 & 8.06 & 0.11 & 0.02 \\
\hline
\end{tabular}

The reason for this study focusing on email usage among academician in Malaysian universities, since previous studies done by Mahomed (2015) had concentrated on email usage of nonacademic staff in the Malaysian public and private universities and excluded academician in his research.

In this study, the academician's in question are involved with duties that cover the scope of research, education, as well as community services, all which involve heavy communication as well as been extensive documentation. It is believed by this research, that speed is crucial in time of delivery as well as efficiency, of the academician which will affect the impact of the entire performance of administration within a university positively.

Consequently, this study seeks to examine two aspects of email usage. First, it will identify the level of email usage of academician in Malaysian public and private universities and comparing the differences in email usage of academician between Malaysian public and private universities. Second, it will create a holistic conceptual framework for analysing the relationship between email usage and technological factor among academician in Malaysian public and private universities using Technology Acceptance Model (TAM) introduced by Davis (1989).

The research will aid the government through contribution of info which will help the Government of Malaysia, to up and advance email communication adoption, specifically towards academicians, therefore having a way to provide an economic that is substantially beneficial.

\section{Literature review}

The literature review highlights on the email usage worldwide and its influence from a technolog- 
ical point of view using the Technology Acceptance Model.

\subsection{Email communication}

As a means of organisational communication, email has been noted for its many advantages such as it lessens usage of paper, remove time delays, allow the sender to convey messages to a list of specific individuals and overcome physical and situational factors associated with faceto-face communications, scheduled meetings and scattered work environments (Ratchukool, 2001; Davidavičienè, Pabedinskaite, \& Davidavičius, 2017; Raudeliūnienè, Davidavičienė, Tvaronavičiene, \& Jonuška, 2018). Robbins and Judge (2017) also outlined some of the advantages of email such as they can be quickly and cheaply written, edited, sent and stored.

Despite the pros of emails, there are cons which limit email communication which have an impact on the intention of usage, such as misinterpreting the message, communicating negative messages and the time-consuming nature of email (Robbins \& Judge, 2017). Robbins and Judge (2017) also outlined some general barriers which cause disruption in the effectiveness of communication including that of filters, as well as the selective perception, information overload, feelings, language, quietness, communication apprehension, gender differences and communication which is 'politically correct'.

\subsection{Email usage}

Worldwide, email remains the most pervasive form of communication, while other technologies such as social networking, instant messaging (IM), chat, mobile IM, and others are also taking hold, email is still the most ubiquitous form of business communication. In addition, email is integral to the overall Internet experience as an email account (i.e. email address) is required to sign up to any online activity, including social networking sites, instant messaging and any other kind of account or presence on the Internet. In 2018 (until March 2018), the total business counts and consumer emails that were sent as well as received per day will exceed 281 billion, and is forecast to grow to over 333 billion by year-end 2022. The number of worldwide email users will top 3.8 billion in 2018 , and is expected to grow to over 4.2 billion by the end of 2022. Over half of the world population uses email in 2018 (Radicati, 2018).
Table 3. Worldwide email user forecast (M), 20182022 (source: Reproduced from Radicati, 2018)

\begin{tabular}{|l|l|l|l|l|l|}
\hline & 2018 & 2019 & 2020 & 2021 & 2022 \\
\hline $\begin{array}{l}\text { Worldwide } \\
\text { Email Users* } \\
(\mathrm{M})\end{array}$ & 3,823 & 3,930 & 4,037 & 4,147 & 4,258 \\
\hline$\%$ Growth & - & $3 \%$ & $3 \%$ & $3 \%$ & $3 \%$ \\
\hline
\end{tabular}

*Note: Includes both Business and Consumer Email users

In Malaysian universities, Mahomed (2015) on email usage levels centred around non-academic staff in Malaysian public and private universities found universities that were private had a significantly larger number of received official emails usage when put side by side with public universities with the mean rank for private universities was 234.41 while for public universities only 173.44 at 0.05 significance level. Detail findings on email received in Malaysia for both public and private universities, suggested that $30.1 \%$ of the respondents received $6-10$ messages per day, $21.9 \%$ of the respondents received more than 20 messages per day, $17.4 \%$ received $16-20$ messages per day, $15.4 \%$ got about three to five messages per day and $14.9 \%$ got 11 to 15 messages. One respondent was said to only have received less than or equal to two messages (Mahomed, 2015).

Whilst findings for email sent between Malaysian public and private universities, suggested that one-third of the respondents (33.3\%) sent 35 messages per day. For the frequent users, $20.1 \%$ sent 6-10 messages daily, $11.7 \%$ sent $16-20$ messages per day, 9\% sent out a larger than 20 messages per day. In the meantime, 33 respondents (8.2 per cent) sent $11-15$ messages a day. $0.5 \%$ or two respondents were the only ones that sent messages that were less than two or equal in a day. In addition, a mean rank of 172.26 for public universities and 235.79 for private universities clearly reflect that private universities have higher numbers of official emails sent compared to public universities $\mathrm{p}$-value $\approx 0.00$ (Mahomed, 2015). However, the finding may be different among academician in Malaysian public and private universities which would have been one of the outcome of this study.

This study use a wholesome work of frame in its analysis to study the email usage relationship between technological factor among academician in Malaysian public and private universities using Technology Acceptance Model (TAM) introduced by Davis (1989). TAM has been accepted as a reliable model to describe and predict user acceptance of technology due to its versatility (Venkatesh \& Davis, 2000), parsimony and predictive 
power (Mahomed, 2015). This makes it the most popular as well as widely employed model when it comes to studies on technological acceptance (McCoy, Galetta, \& King, 2007).

Even newer studies done by Rahman, Lesch, Horrey, and Strawdermana (2017) on assessing the utility of technology Acceptance Model (TAM), Theory of Planned Behavior (TPB) and UTAUT Unified Theory of Acceptance and Use of Technology (UTAUT) for advanced driver assistance systems found that the models (TAM, TPB, and UTAUT) can explain driver acceptance with their proposed sets of factors, each explaining $71 \%$ or more of the variability in Behavioral Intention. Among the models, however TAM was found to perform the best in modelling driver acceptance followed by TPB (Rahman et al., 2017).

TAM also possesses the adaptability as well as the ability in being an interactive moderator of national cultures in studies which are international (McCoy et al., 2007), Western countries (Davis, 1989), Eastern countries (Al-Sukkar, 2005; Alhujran, 2009) and Malaysia (Mahomed, 2015; Mahomed, McGrath, \& Keating, 2015; Mahomed, McGrath, \& Yuh, 2017a; Mahomed, McGrath, Yuh, \& Mokhtar, 2017b). TAM is simple enough to be implemented throughout difference national cultures. Several studies using TAM on email communication have obtained results very believable results in countries in the west (Davis, 1989), Eastern countries (Al-Sukkar, 2005; Alhujran, 2009) and Malaysia (Baninajarian, 2009; Mahomed, 2015; Mahomed et al., 2015; Mahomed et al., 2017a, 2017b). TAM can be applied to different kinds of situations and be integrated with factors of rural/urban location, gender, age, race, religion and types of organisation (Mahomed, 2015).

\subsection{Malaysian higher education institutions}

Based on the Ministry of Higher Education of Malaysia (2018), public and private universities numbers are as show in Figure 1. Noticed that majority of Malaysia universities are private (96\%) compared to $4 \%$ only for public universities.

\subsection{Technology Acceptance Model (TAM)}

Davis, Bagozzi, and Warshaw (1989) explained in his intro of TAM: "The goal of TAM is to provide an explanation of the determinants of computer acceptance that is general, capable of explaining user behaviour across a broad range of end-user computing technologies and user populations" (Davis et al., 1989).

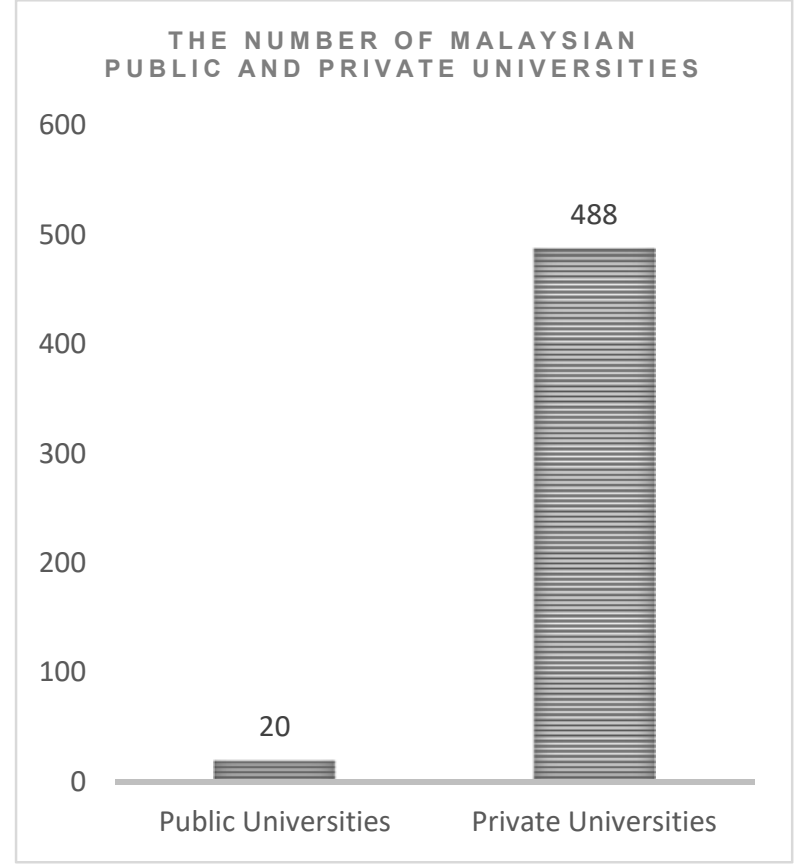

Figure 1. The number of Malaysian public and private universities (source: Ministry of Higher Education, Malaysia, 2018)

Davis (1989) depended on many other studies that were interconnected in order to conceptualise the very different constructs which are perceived usefulness and perceived ease of use of use as shown in Figure 2.

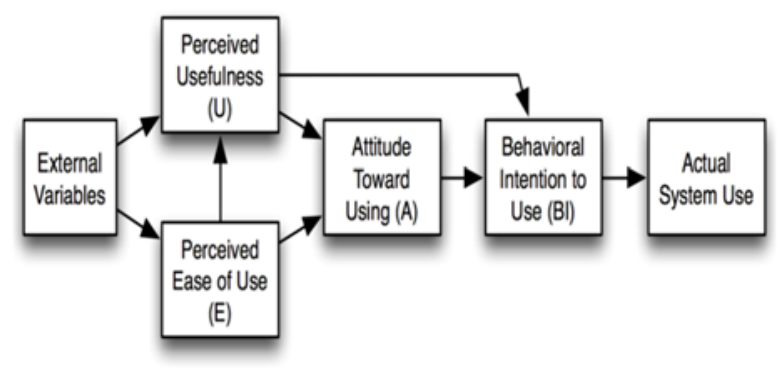

Figure 2. Technology Acceptance Model (source: Davis, 1989)

\section{Perceived Usefulness (PU)}

Perceived Usefulness (PU) is defined as "the degree to which a person believes that using a particular system would enhance his or her job performance" (Davis, 1989). PU has been suggested by many studies to provide a significant positive result in relation to technology adoption through various technologies usage (Davis, 1989; Al-Sukkar, 2005; Alhujran, 2009; Rahman et al., 2017) and email usage (Mutlu \& Ergeneli, 2012; Mahomed, 2015; Mahomed et al., 2015; Mahomed et al. 2017a, 2017b, 2017c). 
H1: Perceived usefulness (PU) positively impacts significantly email usage (U) among academician in Malaysian public universities.

Perceived Ease of Use (PEOU)

Perceived Ease of Use (PEOU) is defined as "the degree to which a person believes that using a particular system would be free of effort" (Davis, 1989). Ease defined as "freedom from difficulty or great effort" (Davis, 1989). PEOU has been suggested by many studies to provide a significant positive result in relation to technology adoption through various technologies usage (Davis, 1989; Al-Sukkar, 2005; Alhujran, 2009; Rahman et al., 2017) and email usage (Mahomed, 2015; Mahomed et al., 2015; Mahomed et al. 2017a, 2017b). Davis (1989) suggests that PEOU causally affects PU. Therefore, a system that is developed for easier usage would likely make the system more useful (Davis, 1989).

H2: There is a significant positive relationship between Perceived Ease of Use (PEOU) and email usage (U) in Malaysian private universities.

H3: There is a significant positive relationship between Perceived Ease of Use (PEOU) and perceived usefulness (PU) on email usage in $\mathrm{Ma}$ laysian private universities.

\subsection{Hypotheses}

Table 4. Hypotheses for testing

\begin{tabular}{|l|l|}
\hline Code & \multicolumn{1}{|c|}{ Hypothesis } \\
\hline H1a: & $\begin{array}{l}\text { Perceived ease of use (PEOU) has significant } \\
\text { positive effect on perceived usefulness (PU) } \\
\text { among academician pertaining to email usage in } \\
\text { Malaysian public universities. }\end{array}$ \\
\hline H1b: & $\begin{array}{l}\text { Perceived ease of use (PEOU) has significant } \\
\text { positive effect on perceived usefulness (PU) } \\
\text { among academician pertaining to email usage in } \\
\text { Malaysian private universities. }\end{array}$ \\
\hline H2a: & $\begin{array}{l}\text { Perceived usefulness (PU) has significant posi- } \\
\text { tive influence on email usage (U) among acade- } \\
\text { mician in Malaysian public universities. }\end{array}$ \\
\hline H2b: & $\begin{array}{l}\text { Perceived usefulness (PU) has significant posi- } \\
\text { tive influence on email usage (U) among acade- } \\
\text { mician in Malaysian private universities. }\end{array}$ \\
\hline H3a: & $\begin{array}{l}\text { Perceived ease of use (PEOU) has significant } \\
\text { positive impact on email usage (U) among acad- } \\
\text { emician in Malaysian public universities. }\end{array}$ \\
\hline H3b: & $\begin{array}{l}\text { Perceived ease of use (PEOU) has significant } \\
\text { positive impact on email usage (U) among acad- } \\
\text { emician in Malaysian private universities. }\end{array}$ \\
\hline H4a: & $\begin{array}{l}\text { University types moderate the relationship of } \\
\text { perceived ease of use (PEOU) on perceived use- } \\
\text { fulness (PU) among academician. }\end{array}$ \\
\hline $\begin{array}{l}\text { University types moderate the relationship of } \\
\text { perceived ease of use (PEOU) on email usage } \\
\text { (U) among academician. }\end{array}$ \\
\hline
\end{tabular}

End of Table 4

\begin{tabular}{|l|l|}
\hline Code & \multicolumn{1}{|c|}{ Hypothesis } \\
\hline H4c: & $\begin{array}{l}\text { University types moderate the relationship of } \\
\text { perceived usefulness (PU) on email usage (U) } \\
\text { among academician. }\end{array}$ \\
\hline H5a & $\begin{array}{l}\text { There is significant mediation effect of per- } \\
\text { ceived usefulness (PU) on the relationship of } \\
\text { perceived ease of use (PEOU) and email usage } \\
\text { (U) among academician in Malaysian public } \\
\text { universities }\end{array}$ \\
\hline H5b & $\begin{array}{l}\text { There is significant mediation effect of per- } \\
\text { ceived usefulness (PU) on the relationship of } \\
\text { perceived ease of use (PEOU) and email usage } \\
\text { (U) among academician in Malaysian private } \\
\text { universities }\end{array}$ \\
\hline
\end{tabular}

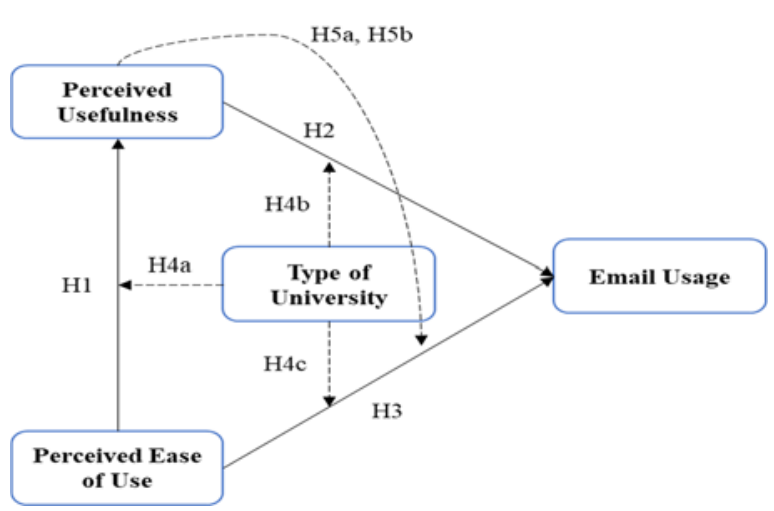

Figure 3. Research model adopted from Davis (1989)

By conciliating the PEOU and PU on Technology Acceptance Model, the hypotheses for testing as in Table 4 and the research model is shown in illustrated in Figure 3.

\section{Methodology}

Around 400 questionnaires have been distributed in two types of universities, whereby 274 valid questionnaires were collected, concluding with a $68.5 \%$ percent response rate. The universities were chosen randomly using list of public and private universities in Malaysia and systematic random sampling was employed to choose the respondents. In addition, questionnaires have been self-administrated, which resulted in high response rate. The questionnaires can be group into two categories, which are demography and technology acceptance. Demography part measures the basic profile of respondents as well as their actual usage of email. Then, Technology Acceptance Model part measures perceived ease of use (PEOU), perceived usefulness (PU) and actual usage (U) of email. In regards to PEOU and PU, the measurement scale developed through Davis 
(1989). When it came to actual usage determination, scales created by Hart and Porter (2004), and adopted by Hung (2011) and Mahomed (2015) were found compatible with objects that were of actual usage as affirmed through respondents (in demography part), i.e. such as the emails that were sent and received. In order to create a measurement which ranged from 1 (strongly disagree) to 5 (strongly agree), a 5-point Likert scale was adopted. In the meantime, a number of determined response choices were incorporated in regards to the demographic section.

Partial Least Square (PLS) is used in this research to validate the research model and hypotheses testing. The PLS analysis is presented in terms of the measurement model and then the structural model using SmartPLS 2.0. According to Hair, Black, Babin, and Anderson (2010) PLSSEM is a complete multivariate statistical analysis method that can at the same time investigate relationships among all of the constructs in a research model, including a measurement component and a structural component. Reinartz, Haenlein, and Henseler (2009) suggests that a threshold of 100 samples for PLS-SEM analysis, therefore the samples of this study is 274 respondents which above the threshold needed.

\section{Results}

Table 5 shows the respondents' demographic factors separated by type of universities. Private universities in Malaysia were found to have more female academician (60.9\%) compared to public universities. Further, private universities in Malaysia were found to have more Malay academic staffs (95.9\%) and more Muslim academician $(97.3 \%)$. For the age groups, results showed private universities are having younger academician than public universities in Malaysia in which $72 \%$ of respondents in private universities are 35 years old and below compared to only about $44 \%$ in public universities. For academician in public universities, noticed that most of them have at least Master degree while private universities still have some of them having Bachelor degree (25\%).

\subsection{Assessment of measurement model}

Prior in testing the structural model, it is crucial to assess the reliability, convergent validity and discriminant validity of measurement model. Table 6 presents the final factor loading, composite reliability (C.R.) and average variance explained (AVE) values for assessment. It is important to state that item PEOU2 and PU3 were taken out of model from both public and private universities due to low or insignificant factor loading. Noticed that all composite reliability coefficients were greater than 0.7 , suggesting reliable measurement model for public and private universities data. Also, as shown in Table 7, the model exhibited good convergent validity for both public and private universities as all AVE values are greater than 0.5 (Hair et al., 2010).

Table 5. Respondents' profile

\begin{tabular}{|c|c|c|c|c|}
\hline \multirow{2}{*}{ Factor } & \multicolumn{2}{|c|}{ Public } & \multicolumn{2}{|c|}{ Private } \\
\hline & Count & Percent & Count & Percent \\
\hline \multicolumn{5}{|l|}{ Gender } \\
\hline Male & 67 & 45.9 & 50 & 39.1 \\
\hline Female & 79 & 54.1 & 78 & 60.9 \\
\hline \multicolumn{5}{|l|}{ Races } \\
\hline Malay & 140 & 95.9 & 57 & 44.5 \\
\hline Chinese & 4 & 2.7 & 61 & 47.7 \\
\hline Indian & 2 & 1.4 & 10 & 7.8 \\
\hline \multicolumn{5}{|l|}{ Religion } \\
\hline Muslim & 142 & 97.3 & 57 & 44.5 \\
\hline Buddhist & 2 & 1.4 & 49 & 38.3 \\
\hline Hindu & 1 & 0.7 & 8 & 6.3 \\
\hline Christian & 1 & 0.7 & 12 & 9.4 \\
\hline Other & 0 & 0 & 2 & 1.6 \\
\hline \multicolumn{5}{|l|}{ Age } \\
\hline $20-25$ years & 8 & 5.5 & 14 & 10.9 \\
\hline $26-30$ years & 44 & 30.1 & 48 & 37.5 \\
\hline $31-35$ years & 27 & 18.5 & 31 & 24.2 \\
\hline $36-40$ years & 21 & 14.4 & 9 & 7 \\
\hline $41-45$ years & 8 & 5.5 & 7 & 5.5 \\
\hline $46-50$ years & 16 & 11 & 12 & 9.4 \\
\hline $51-55$ years & 19 & 13 & 5 & 3.9 \\
\hline 56-60 years & 3 & 2.1 & 0 & 0 \\
\hline Over 60 years & 0 & 0 & 2 & 1.6 \\
\hline \multicolumn{5}{|l|}{ Education } \\
\hline Bachelor & 0 & 0 & 32 & 25 \\
\hline Master & 104 & 71.2 & 76 & 59.4 \\
\hline $\mathrm{PhD}$ & 42 & 28.8 & 20 & 15.6 \\
\hline \multicolumn{5}{|l|}{ Position } \\
\hline N/A & 2 & 1.4 & 2 & 1.6 \\
\hline Professor & 3 & 2.1 & 29 & 22.7 \\
\hline Ass. Professor & 3 & 2.1 & 44 & 34.4 \\
\hline Sr. Lecturer & 23 & 15.8 & 53 & 41.4 \\
\hline Lecturer & 19 & 13 & 0 & 0 \\
\hline Jr. Lecturer & 96 & 65.8 & 0 & 0 \\
\hline
\end{tabular}


Table 6. Statistics for reliability and convergent validity

\begin{tabular}{|c|c|c|c|c|c|c|}
\hline & \multicolumn{3}{|c|}{ Public } & \multicolumn{3}{|c|}{ Private } \\
\hline Items & Loading & C.R. & AVE & Loading & C.R. & AVE \\
\hline AU_1 & 0.715 & 0.864 & 0.559 & 0.900 & 0.938 & 0.751 \\
\hline AU 2 & 0.764 & & & 0.861 & & \\
\hline AU_3 & 0.768 & & & 0.874 & & \\
\hline U1 & 0.736 & & & 0.821 & & \\
\hline $\mathrm{U} 2$ & 0.754 & & & 0.875 & & \\
\hline PEOU1 & 0.899 & 0.935 & 0.784 & 0.887 & 0.917 & 0.735 \\
\hline PEOU3 & 0.893 & & & 0.846 & & \\
\hline PEOU4 & 0.849 & & & 0.812 & & \\
\hline PEOU5 & 0.899 & & & 0.882 & & \\
\hline PU1 & 0.746 & 0.839 & 0.566 & 0.935 & 0.954 & 0.837 \\
\hline PU2 & 0.755 & & & 0.929 & & \\
\hline PU4 & 0.772 & & & 0.901 & & \\
\hline PU5 & 0.738 & & & 0.893 & & \\
\hline $\begin{array}{l}\mathrm{AU}=\mathrm{A} \\
\mathrm{PEOU}= \\
\text { ness }\end{array}$ & $\begin{array}{l}\text { al Usag } \\
\text { rceived }\end{array}$ & $\mathrm{U}=$ & & & & cul- \\
\hline
\end{tabular}

Table 7. Multiple correlation matrix for constructs

\begin{tabular}{|c|c|c|c|c|c|c|}
\hline & \multicolumn{3}{|c|}{ Public } & \multicolumn{3}{c|}{ Private } \\
\hline Constructs & PEOU & PU & U & PEOU & PU & U \\
\hline PEOU & 0.885 & & & 0.857 & & \\
\hline PU & 0.695 & 0.753 & & 0.692 & 0.915 & \\
\hline U & 0.728 & 0.643 & 0.748 & 0.749 & 0.841 & 0.866 \\
\hline Diagonal values are square root of AVE \\
\hline
\end{tabular}

As suggested by Hair et al. (2010), the square root of AVE value of a particular construct need to be higher compared to its correlation with other constructs. This will ensure that the underlying items of that particular explain more of its own construct variances than other constructs. Table 3 shows the multiple correlation matrix of the three constructs involved. Noticed that the square roof AVE values were greater than their corresponding correlation values in both public and private universities model, indicating that measurement model has satisfactory discriminant validity for both type of universities.

\subsection{Results of structural equation modelling}

Figure 4 depicts the structural equation modelling of academician data for both public and private universities conducted using SmartPLS 2.0. Table 8 summarised the path estimations results for both public and private universities, together with their $\mathrm{R}^{2}$ values. From the results, study noticed that the model can better explain the email usage among academician in private universities $\left(\mathrm{R}^{2}=0.760\right)$ compared to public universities $\left(\mathrm{R}^{2}=0.566\right)$.

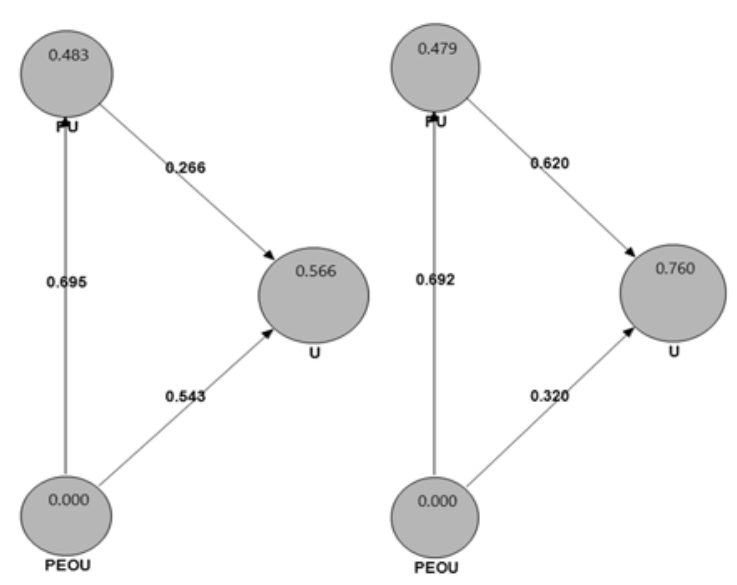

Figure 4. Structural model

$($ left $=$ public; right $=$ private $)$

Table 8. Path estimations (BETA) of model

\begin{tabular}{|c|c|c|c|c|c|c|}
\hline \multicolumn{3}{|c|}{ Path } & Direct & Indirect & Total & $\begin{array}{l}\text { Path diff. } \\
\text { (p value) }\end{array}$ \\
\hline \multicolumn{3}{|c|}{ Public } & & & & \\
\hline PU & $<-$ & PEOU & $0.695^{*}$ & NIL & $0.695^{*}$ & 0.9735 \\
\hline $\mathrm{U}$ & $<--$ & PEOU & $0.543^{*}$ & $0.185^{*}$ & $0.728 *$ & 0.0197 \\
\hline $\mathrm{U}$ & $<--$ & PU & $0.266^{*}$ & NIL & $0.266^{*}$ & $\approx 0.000$ \\
\hline \multicolumn{3}{|c|}{ Private } & & & & \\
\hline PU & $<--$ & PEOU & $0.692 *$ & NIL & $0.692 *$ & 0.9735 \\
\hline $\mathrm{U}$ & $<-$ & PEOU & $0.320^{*}$ & $0.429 *$ & $0.749 *$ & 0.0197 \\
\hline $\mathrm{U}$ & $<--$ & PU & $0.620^{*}$ & NIL & $0.620^{*}$ & $\approx 0.000$ \\
\hline \multicolumn{7}{|c|}{$\mathrm{R}^{2}($ public $)=0.566 ; \mathrm{R}^{2}$ (private $)=0.760$} \\
\hline \multicolumn{7}{|c|}{ * significant at 0.05} \\
\hline
\end{tabular}

In terms of structural model, PEOU has significant positive influence on PU for public and private universities' academician with BETA value of 0.695 and 0.692 . If academician perceived that the emails is easy to use, they will likely to think that it is useful. Next, PEOU has significant positive effect on $U$ for academic staffs of public and private universities, proven with BETA value of 0.543 and 0.429 .

This finding shows that when academician think emails is easy to use, their usage of emails will likely to increase. Finally, study found that PU has significant positive impact on $U$ for the academician in both universities. The BETA value of 0.266 and 0.620 implying that if academician think that emails is useful, they will have higher chances in using emails. Next, results revealed that PU mediate the relationship of PEOU towards PU in both universities with significant indirect effect of 0.185 and 0.429 . Notice that ef- 
fect of PEOU on U remained significant even mediated by PU, thus PU only partially mediate the relationship of PEOU on $U$ for both type of universities.

Apart from that, Chi-square test was employed to test the path different between the public and private universities. Based on results, there is significant different in the impact of PEOU towards $U$ and PU towards $U$, thus type of universities moderate the strength of relationships. Looking at the BETA value, noticed that for public universities (0.543), the academician that think emails is useful will more likely to use it as compared to the academician from private universities (0.320). Further, academician from private universities $(0.620)$ who believed emails is useful will tend to use it as compared to academician from public universities (0.266).

Table 9. Official emails usage comparison

\begin{tabular}{|l|l|c|c|c|c|}
\hline \multicolumn{1}{|c|}{ Email Usage } & Type & $\mathrm{N}$ & Mean & S.D. & $\mathrm{p}$ value \\
\hline Frequency & Public & 146 & 5.69 & 1.441 & 0.001 \\
\hline & Private & 128 & 6.28 & 1.345 & \\
\hline Emails received & Public & 146 & 5.60 & 1.484 & $\approx 0.000$ \\
\hline & Private & 128 & 6.34 & 1.226 & \\
\hline Emails sent & Public & 146 & 5.75 & 1.384 & $\approx 0.000$ \\
\hline & Private & 128 & 6.42 & 1.233 & \\
\hline
\end{tabular}

Table 9 summarised the results of independent $t$ test to examine the actual emails usage between academician of public and private universities. Based on results, all the $p$ values were less than 0.05 , indicating that there are significant in the usage of emails between public and private universities academician. Perusal of table, noticed that for frequency of usage, emails received per day and emails sent per day, academician from private universities showed higher mean values compared to public universities. Referring back to questionnaire's code, academician from public universities are using about three times per day $($ mean $=5.69)$ while academician from private universities are using about five times per day (mean $=6.28)$. For public universities, academician received about 13 emails per day while academician from private universities received about 17 emails per day. Lastly, private universities' academician sent more emails (17 emails) compared to public universities (13 emails). The summary of hypotheses testing as shown in Table 10 .
Table 10. Summary of hypotheses testing

\begin{tabular}{|c|c|c|}
\hline Code & Hypothesis & $\begin{array}{c}\text { Sup- } \\
\text { ported }\end{array}$ \\
\hline H1a: & $\begin{array}{l}\text { Perceived ease of use (PEOU) has } \\
\text { significant positive effect on per- } \\
\text { ceived usefulness (PU) among } \\
\text { academician pertaining to email us- } \\
\text { age in Malaysian public universi- } \\
\text { ties. }\end{array}$ & Yes \\
\hline $\mathrm{H} 1 \mathrm{~b}$ : & $\begin{array}{l}\text { Perceived ease of use (PEOU) has } \\
\text { significant positive effect on per- } \\
\text { ceived usefulness (PU) among } \\
\text { academician pertaining to email us- } \\
\text { age in Malaysian private universi- } \\
\text { ties. }\end{array}$ & Yes \\
\hline H2a: & $\begin{array}{l}\text { Perceived usefulness (PU) has sig- } \\
\text { nificant positive influence on email } \\
\text { usage (U) among academician in } \\
\text { Malaysian public universities. }\end{array}$ & Yes \\
\hline $\mathrm{H} 2 \mathrm{~b}:$ & $\begin{array}{l}\text { Perceived usefulness (PU) has sig- } \\
\text { nificant positive influence on email } \\
\text { usage (U) among academician in } \\
\text { Malaysian private universities. }\end{array}$ & Yes \\
\hline H3a: & $\begin{array}{l}\text { Perceived ease of use (PEOU) has } \\
\text { significant positive impact on email } \\
\text { usage (U) among academician in } \\
\text { Malaysian public universities. }\end{array}$ & Yes \\
\hline $\mathrm{H} 3 \mathrm{~b}:$ & $\begin{array}{l}\text { Perceived ease of use (PEOU) has } \\
\text { significant positive impact on email } \\
\text { usage (U) among academician in } \\
\text { Malaysian private universities. }\end{array}$ & Yes \\
\hline H4a: & $\begin{array}{l}\text { University types moderate the rela- } \\
\text { tionship of perceived ease of use } \\
\text { (PEOU) on perceived usefulness } \\
\text { (PU) among academician. }\end{array}$ & No \\
\hline $\mathrm{H} 4 \mathrm{~b}:$ & $\begin{array}{l}\text { University types moderate the rela- } \\
\text { tionship of perceived ease of use } \\
\text { (PEOU) on email usage (U) among } \\
\text { academician. }\end{array}$ & Yes \\
\hline H4c: & $\begin{array}{l}\text { University types moderate the rela- } \\
\text { tionship of perceived usefulness } \\
\text { (PU) on email usage (U) among } \\
\text { academician. }\end{array}$ & Yes \\
\hline $\mathrm{H} 5 \mathrm{a}$ & $\begin{array}{l}\text { There is significant mediation ef- } \\
\text { fect of PU on the relationship of } \\
\text { perceived ease of use (PEOU) and } \\
\text { email usage (U) among academi- } \\
\text { cian in Malaysian public universi- } \\
\text { ties. }\end{array}$ & Yes \\
\hline $\mathrm{H} 5 \mathrm{~b}$ & $\begin{array}{l}\text { There is significant mediation ef- } \\
\text { fect of PU on the relationship of } \\
\text { perceived ease of use (PEOU) and } \\
\text { email usage (U) among academi- } \\
\text { cian in Malaysian private univer- } \\
\text { sities. }\end{array}$ & Yes \\
\hline
\end{tabular}

\section{Discussion}

This research examines and compares email usage levels of among academician in Malaysian public and private universities. Findings showed that actual email usage (sending and receiving of email) 
among academician is significantly higher in Malaysian private universities (mean $=6.34$ and 6.42) than in public universities (mean $=5.6$ and 5.75), albeit the usage levels were high for both types of universities. The significant of this study is consistent with the previous study done by Mahomed (2015) which found that email usage (sending and receiving of email) among non-academic staff is significantly higher in Malaysian private universities than in public universities. It is interesting to find that academic staff have higher email usage (sending and receiving of email) as compared to non-academic staff. Data from non-academic staff in Malaysia universities (Mahomed, 2015) showed that $39.3 \%$ of non-academic staff received 16 messages and above in a day, while as high as $86.2 \%$ of academic staff in this study received the same amount of email. In addition, Mahomed (2015) data showed that $20.7 \%$ of non-academic staff in Malaysia universities sent 16 messages and above per day, while $86.7 \%$ of academic staff in this study sent the same amount of email.

The findings demonstrated that the perceived ease of use (PEOU) as well as the perceived usefulness (PU) in the Technology Acceptance Model (TAM) had a noteworthy connection with email usage among academician in both Malaysian public and private universities. What has been found is consistent with older research on the significant positive relationship between PU and PEOU on technology usage (Baninajarian, 2009; Mutlu \& Ergeneli, 2012; Mahomed, 2015; Mahomed et al. 2015; Mahomed et al., 2017a, 2017b, 2017c).

However, Malaysian private universities were founded to have higher and stronger effect of perceived usefulness (PU) on email usage as compared to Malaysian public universities. This finding shows that with the same magnitude of the increment in the level of PU, private universities will likely result in higher increment in email usage (U). On perceived ease of use (PEOU), results showed that there are no significant differences in its effect on email usage between Malaysian public and private universities. This means that based on TAM, the higher email usage in Malaysian private universities depends more on the user's perception of email usefulness rather than perception of ease of use.

\section{Limitation}

The limitations were sort of linked weakness in methodology, namely because the research model accounts about 56.6 per cent and 76.0 per cent only of the actual email usage in Malaysian public and private universities. Further, the study also involved only public and private universities found in Peninsular Malaysia and excluded East Malaysia, which is the Borneo.

\section{Conclusions}

In conclusion, the email usage among academician in Malaysian private universities is higher as compared with their counterpart in Malaysian public universities. Secondly, all hypotheses were supported except one hypothesis where university types did not moderate the relationship of perceived ease of use (PEOU) on perceived usefulness (PU) among academician. Both PEOU and PU have an effect on usage of emails adoption among academician in Malaysian public and private universities. Finally, it can be conclude that the higher email usage in Malaysian private universities depends more on the user's perception of email usefulness rather than perception of ease of use.

\section{Funding}

This work was supported by the Universiti Putra Malaysia [Putra Grant 9511300] and Committee of Overseas Conference/Workshops, Universiti Putra Malaysia.

\section{Disclosure Statement}

The authors declares that (s)he has no relevant or material financial interests that relate to the research described in this paper.

\section{References}

Al-Sukkar, A. S. (2005). The application of information systems in the Jordanian banking sector: a study of the acceptance of the internet ( $\mathrm{PhD}$ thesis). University of Wollongong, Australia.

Alhujran, O. (2009). Determinants of e-government services adoption in developing countries: a field survey and a case study (PhD thesis). University of Wollongong, Australia.

Baninajarian, N. (2009). The role of email in improving task performance among staffs at multimedia University, Malaysia (Master thesis). Universiti Putra Malaysia.

Beechler, D. (2014). Email is the foundation for online communication in Southeast Asia. Retrieved from https://www.marketingcloud.com/blog/au/email-isthe-foundation-for-online-communication-in-southeast-asia/ 
Davidavičienè, V., Pabedinskaitė, A. O., \& Davidavičius, S. (2017). Social networks in B2B and B2C Communication. Transformations in Business and Economics, 16(1), 69-84.

Davis, F. D. (1989). Perceived usefulness, perceived ease of use, and user acceptance of information technology. MIS Quarterly, 13(3), 319-340. https://doi.org/10.2307/249008

Davis, F. D., Bagozzi, R. P., \& Warshaw, P. R. (1989). User acceptance of computer technology: a comparison of two theoretical models. Management Science, 35(8), 982-1003. https://doi.org/10.1287/mnsc.35.8.982

Dawam, S. R. M., Ahmad, K. A., Jusoff, K., Tajuddian, T., Elias, S. J., \& Mansor, S. W. (2009). The use of ICT in public and private institutions of higher learning, Malaysia. Computer and Information Science, 2(4), 122128. https://doi.org/10.5539/cis.v2n4p122

Get Response. (2017). Southeast Asia email marketing benchmarks. Retrieved from https://multimedia.getresponse.com/getresponse-BssS4/docments/ 603061703.pdf?ga $=2.4239 \quad 536.2031530838 \quad 152065$ 2823-840688022.1520652 823

Hair, J. F., Black, W., Babin, B. J., \& Anderson, R. (2010). Multivariate data analysis: a global perspective. Pearson Prentice Hall, New Jersey.

Hart, M., \& Porter, G. (2004). The impact of cognitive and other factors on the perceived usefulness of OLAP. Journal of Computer Information Systems, 45(1), 4756.

Hung, V. Q. (2011). Applying technology acceptance model in evaluating the usage of MISA accounting software at SME's-Nam Dinh Province, Vietnam (Master thesis). Shu-Te-University.

Mahomed, A. S. B. (2015). Examining email usage among non-academic staff in public and private Malaysian Universities ( $\mathrm{PhD}$ Thesis). Victoria University Melbourne, Australia.

Mahomed, A. S. B., McGrath, G. M., \& Keating, M. (2015). Email usage among youth in Malaysian public and private Universities. Malaysian Journal of Youth Studies, 13(8), 120-152.

Mahomed, A. S. B., McGrath, G. M., \& Yuh, B. Z. (2017a). The role of national culture on email usage among nonacademic staff in Malaysian Public Universities. International Journal of Economics and Management, 11(1), 153-185.
Mahomed, A. S. B., McGrath, G. M., Yuh, B. Z., \& Mokhtar, S. S. S. (2017b). The role of location on email usage in Malaysian Public and Private Universities. International Journal of Applied Business and Economic Research, 15(24), 437-454.

Mahomed, A. S. B., McGrath, G. M., Yuh, B. Z., Othman, Z., Manavalan, K., \& Raman, K. (2017c). The influences of organisational culture on email usage in Malaysian Private Universities. International Journal of Economics and Management, 1(3), 733-762.

McCoy, S., Galetta, D. F., \& King, W. R. (2007). Applying TAM across cultures: the need for caution. European Journal of Information Systems, 16(1), 81-90. https://doi.org/10.1057/palgrave.ejis.3000659

Ministry of Higher Education of Malaysia. (2018). Public Institutions of Higher Education (PIHE). Retrieved from http://jpt.mohe.gov.my/.

Mutlu, S., \& Ergeneli, A. (2012). Electronic mail acceptance evaluation by extended technology acceptance model and moderation effects of espoused national cultural values between subjective norm and usage intention. Intellectual Economics, 6(2), 7-28.

Radicati. (2018). Email Statistics Report, 2018-2022. Palo Alto, CA.

Rahman, M. M., Lesch, M. F., Horrey, W. J., \& Strawdermana, L. (2017). Assessing the utility of TAM, TPB, and UTAUT for advanced driver assistance systems. Accident Analysis and Prevention, 108, 361-373. https://doi.org/10.1016/j.aap.2017.09.011

Raudeliūnienė, J., Davidavičienė, V., Tvaronavičienė, M., \& Jonuška, L. (2018). Evaluation of advertising campaigns on social media networks. Sustainability, 10(4), 1-14. https://doi.org/10.3390/su10040973

Ratchukool, W. (2001). Assessment of email communication (Master thesis). University of Tennessee, Knoxville.

Reinartz, W., Haenlein, M., \& Henseler, J. (2009). An empirical comparison of the efficacy of covariance-based and variance-based SEM. International Journal of Research in Marketing, 26(4), 332-344. https://doi.org/10.1016/j.ijresmar.2009.08.001

Robbins, S. P., \& Judge, T. A. (2017). Organisational behaviour. Pearson Education, Essex, England.

Venkatesh, V., \& Davis, F. D. (2000). A theoretical extension of the technology acceptance model: four longitudinal field studies. Management Science, 46(2), 186-204. https://doi.org/10.1287/mnsc.46.2.186.11926 